\title{
MODEL PENGENDALIAN PENCEMARAN AIR WADUK BATUJAI DI LOMBOK TENGAH, NUSA TENGGARA BARAT
}

\author{
Supardiono $^{1 *}$, Wayan Arthana ${ }^{2)}$, Wayan Sandi Adnyana ${ }^{3)}$, Wayan Budiarsa Suyasa ${ }^{4)}$, \\ Nyoman Sudipa ${ }^{5}$ \\ ${ }^{1)}$ Program Studi Doktor Ilmu Lingkungan, Universitas Udayana \\ ${ }^{2)}$ Fakultas Kelautan dan Perikanan, Universitas Udayana \\ ${ }^{3)}$ Program Studi Agroteknologi, Universitas Udayana \\ ${ }^{4)}$ Fakultas Matematika dan Pengetahuan Alam, Universitas Udayana \\ ${ }^{5)}$ Fakultas Teknik, Universitas Mahendradatta \\ *Email: environmentntb@gmail.com
}

\section{ABSTRACT \\ WATER POLLUTION CONTROL MODEL OF BATUJAI RESERVOIR IN CENTRAL LOMBOK, WEST NUSA TENGGARA}

Water quality management efforts need to be carried out in a sustainable manner to ensure that water resources are free from pollution. Water is an important component in human life, therefore the existence of water in nature must be maintained to ensure the continuity of human life. Decreasing water quality is caused by pollutant loads that enter water bodies due to human activities disposing of waste directly into the water. Batujai Reservoir is one of the vital objects for the survival of the people of Central Lombok. In an effort to control water pollution in the Batujai Reservoir, a model that is capable of managing Batujai Reservoir water is needed in a sustainable manner. The purpose of this research is to develop a model capable of managing the water in the Batujai Reservoir in a sustainable manner. The research methodology uses a quantitative approach using primary data from interviews with figures and experts as well as secondary data from literature studies and previous research data. Data analysis used the Interpretative Structural Modeling (ISM) approach. ISM is able to simplify complex relationships to be simple and form a hierarchy between existing relationships and be able to describe them in the form of system modeling. The results showed that the water pollution control model in Batujai Reservoir was carried out by involving all relevant stakeholders by placing academics, NGOs and Central Lombok Bappeda as the main drivers of program implementation and using the local wisdom approach.

Keywords: pollution, control, water, model, batujai.

\section{PENDAHULUAN}

Air adalah salah satu komponen penting bagi kehidupan manusia. Air tidak hanya menyangkut kuantitas tetapi juga kualitas (Sudipa ${ }_{\mathrm{a}}$ et al., 2020). Pencemaran air terjadi karena bahan buangan yang berasal dari beragam aktivitas masyarakat yang terakumulasi ke dalam air (Panggabean et al., 2016).
Partikel organik dan bakteri di dalam air akan menyebabkan kualitas air menurun dan tidak sesuai dengan peruntukannya (Sudipa $a_{b}$, 2021). Waduk Batujai yang terletak di Lombok Tengah sangat rentan terhadap pencemaran karena segala aktivitas domestik dan usaha akan bermuara di Waduk Batujai. Kondisi ini akan menimbulkan tekanan terhadap Waduk Batujai (Laapo et al, 2009). Waduk Batujai sangat penting 
keberadaannya bagi masyarakat, oleh karena itu perlu langkah-langkah penting untuk menyelamatkan Waduk Batujai dari pencemaran Oleh karena itu penetapan kebijakan yang mempertimbangkan ekuitas, efisiensi, dan keberlanjutan menjadi target utama dalam pengendalian pencemaran Waduk Batujai (Nikoo et al., 2013).

Penurunan kualitas air akan mempengaruhi keberlangsungan ekosistem dan akan berdampak pada menurunnya kualitas lingkungan hidup. Menurunnya kualitas lingkungan akan menyebabkan menurunnya kualitas hidup dan menggangu keseimbangan lingkungan (Sudipa ${ }_{c}$ et al, 2020). Pencemaran air waduk berasal dari berbagai sumber dan bersifat dinamis dan berlangsung dalam waktu yang lama (Maharani et al., 2008). Variabel-variabel dalam penyusunan model mencakup variabel level, variabel rate, dan variabel auxiliary (Zhang et al., 2009). Salah satu penyebab pencemaran lingkungan adalah pola perubahan lahan yang tidak sesuai dengan peruntukannya yang mengakibatkan adanya aktivitas baru yang berpotensi menimbulkan pencemaran (Sudipa $\mathrm{d}_{\mathrm{d}}$ et al, 2020). Model pendekatan baru perlu dibangun untuk mebangunkesadaran baru dalam pemanfaatan sumberdaya air dan pengelolaan secara berkelanjutan (Nandalal dan Sumasinghe, 2006). Salah satu sumber pencemar berasal dari sampah yang masuk ke perairan atau karena sistem pengelolaan sampah yang kurang baik dan menjadi badan air sebagai tempat pembuangan (Armadi et al., 2020). Untuk mengendalikan pencemaran air Waduk Batujai perlu dibangun sebuah model yang mampu berdampak baik terhadap lingkungan hidup (Sudipa $a_{\mathrm{e}}$ et al, 2020). Dalam menyusun elemen dan sub elemen model pengendalian lingkungan dilakukan melalui diskusi dan wawancara secara mendalam dengan tokoh kunci dan pakar dan melibatkan seluruh kepentingan yang ada di wilayah penelitian sehingga dihasilkan hirarki program yang mampu menjawab kebutuhan model pengendalian lingkungan (Kanungo et al., 2009). ISM merupakan permodelan sistem yang mampu menyederhanakan sistem yang rumit (Saxena, 1992).

\section{METODOLOGI}

Metode pengendalian pencemaran air berbasis partisipasi masyarakat menggunakan analisis Interpretative Struktural Modeling (ISM). ISM merupakan permodelan sistem yang mampu merumuskan hal yang berifat komplek dan rumit menjadi sederhana dalam pengendalian pencemaran di Waduk Batujai (Samadikun et al., 2021). Menurut Attri et al. (2013) tahapantahapan dalam operasional ISM adalah:

a. Identifikasi program (elemen sistem) Identifikasi program dilakukan dengan membuat diagram loop pengelolaan waduk seperti pada Gambar 1. 


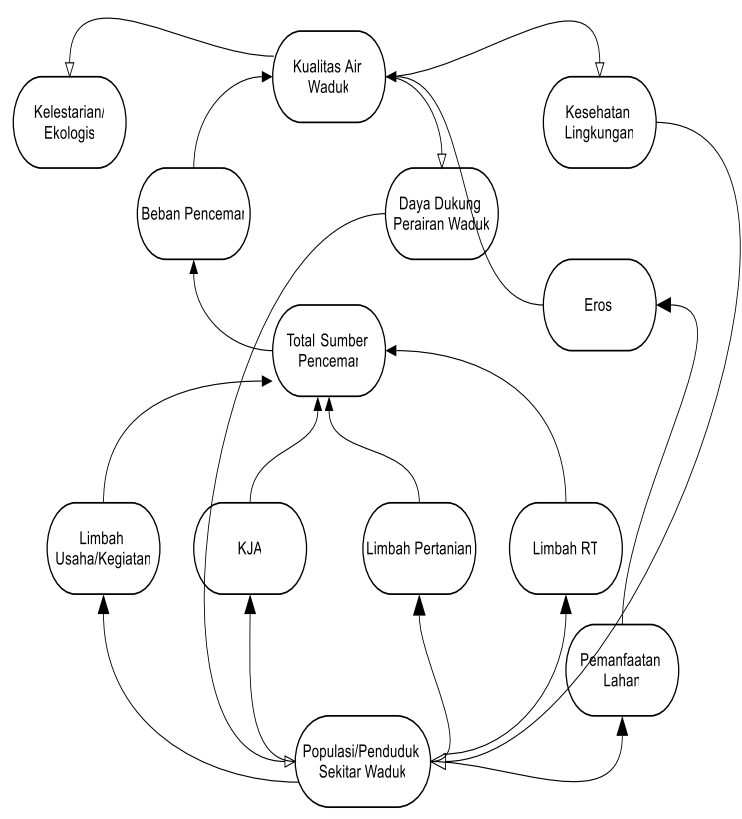

Gambar 1.

Diagram Loop Pengelolaan Waduk Batujai

b. Hubungan kontekstual dan matrik Struktural Self Interaction Matrix (SSIM)

Membuat matrik berdasarkan hasil masukan tokoh dan pakar melalui proses wawancara secara terstruktur.

c. Penyusunan Reachibility Matriks (RM)

Pembuatan matrik berdasarkan hasil wawancara atau persepsi dari pakar dan tokoh sebagai reponden melalui wawancara terfokus yang dipergunakan untuk membuat matrik VAXO.

d. Matriks Driver Power-Dependence untuk elemen tujuan Program

Menyusun hirarki dari setiap elemen yang dikaji dan mengklasifikasikannya atas empat sektor, yaitu sektor autonomous, dependent, linkage dan Independent.

e. Model Struktural Elemen Tujuan

Program

Dari beberapa langkah teknis ISM seperti yang diuraikan di atas maka dibuatkan semacam model struktur elemen ISM dalam mencapai tujuan program pengendalian pencemaran dan kerusakan Waduk Batujai.

\section{HASIL DAN PEMBAHASAN}

\subsection{Elemen \\ Kebutuhan \\ Terlaksananya Program \\ Pengendalian Pencemaran Air}

Hasil analisis terhadap 4 sub elemen kebutuhan terlaksananya program pengendalian pencemaran air memperlihatkan sub elemen kunci adalah Ketersediaan Anggaran (N2). Disamping itu sub elemen sub elemen Ketersediaan Anggaran (N2) berada di sektor IV (Independent) dan mempunyai daya dorong yang kuat terhadap elemen kebutuhan terlaksananya program. Sub elemen Ketersediaan Anggaran (N2) memiliki peranan yang sangat penting dari pengendalian pencemaran air di Waduk Batujai. Sub elemen yang mempunyai daya dorong yang kuat perlu di dahulukan dalam mendukung elemen kebutuhan program (Rosadi et al., 2016) Sub elemen perbaikan sarana sanitasi dan IPAL (N1) 
mempunyai daya penggerak yang cukup kuat terhadap elemen kebutuhan terlaksananya program pengendalian pencemaran air di Waduk Batujai, tetapi kurang kuat dibandingkan dengan sub elemen Ketersediaan Anggaran (N2), karena sub elemen perbaikan sarana sanitasi dan IPAL (N1) berdasarkan Driver Power dan Dependence berada di sektor III (Linkages) yang berarti sub elemen tersebut adalah sub elemen sensitif dan tidak stabil yang perlu kehati-hatian dalam mendukung elemen kebutuhan terlaksananya program pengendalian pencemaran air di Waduk Batujai dalam menyusun model pengendalian pencemaran di Waduk Batujai. Sub elemen Partisipasi Masyarakat (N3) dan sub elemen Koordinasi antar instansi teknis terkait (N4) karena berdasarkan Driver Power dan Dependence berada di sektor II (Dependent) merupakan sub elemen yang tidak bebas dan memiliki pengaruh yang kecil terhadap elemen kebutuhan terlaksananya program pengendalian pencemaran air di Waduk Batujai (Gambar 2). Struktur model hirarki kebutuhan terlaksananya program pengendalian pencemaran air di Waduk Batujai dalam menyusun model pengendalian pencemaran Waduk Batujai yang berdasarkan pengelompokan tertera pada Gambar 3.

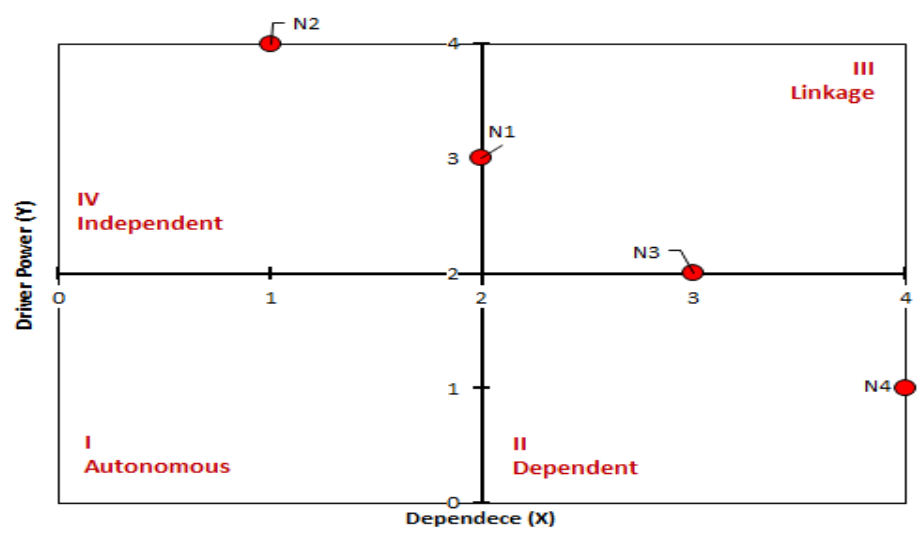

Gambar 2

Hubungan antar sub elemen kebutuhan terlaksananya program

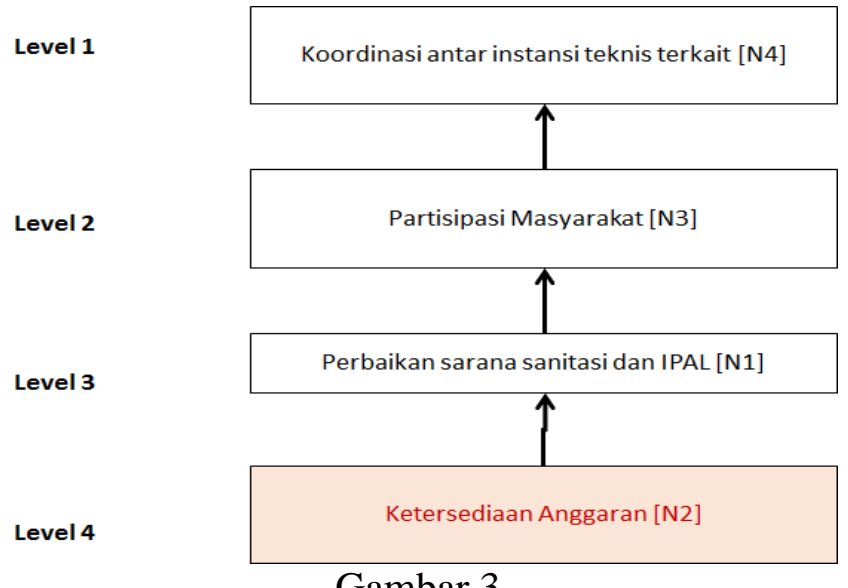

Gambar 3

Struktur sub elemen kebutuhan terlaksananya program 


\subsection{Kendala Utama dalam Pengendalian Pencemaran Air Waduk Batujai}

Hasil analisis terhadap 10 sub elemen kendala utama dalam pengendalian pencemaran air Waduk Batujai dipeoleh hasil bahwa Partisipasi Masyarakat Masih Rendah (B2) dan Keberpihakan Pemerintah Provinsi dan Kabupaten (B3). Sub elemen Partisipasi Masyarakat Masih Rendah (B2) dan Keberpihakan Pemerintah Provinsi dan Kabupaten (B3) sebagai penggerak utama terhadap elemen kendala utama dalam pengendalian pencemaran air waduk Batujai karena sub elemen Partisipasi Masyarakat Masih Rendah (B2) dan Keberpihakan Pemerintah Provinsi dan Kabupaten (B3) mempunyai daya dorong yang kuat terhadap elemen kendala utama pengendalian pencemaran air Waduk Batujai. Sub elemen Ketersediaan Sumber Daya Manusia (B1), Ketersediaan Anggaran (B4), Kebijakan Pengendalian Waduk (B5), Regulasi yang Kurang Jelas (B6), Lemahnya Penegakan Hukum (B7), Penerapan green agriculture (B8), Koordinasi yang Lemah (B9), dan Organisasi Pengelola Belum Jelas (B10) mempunyai daya dorong yang cukup kuat, tetapi perlu kehati-hatian dalam penerapannya. Patisipasi masyarakat perlu didorong untuk meningkatkan capaian program, karena partisipasi masyarakat merupakan kendala utama program pengendalian pencemaran air dengan melakukan edukasi, sosialisasi dan penyuluhan (Pramono et al., 2017).

Secara hirarki Sub elemen Partisipasi Masyarakat Masih Rendah (B2) dan Keberpihakan Pemerintah Provinsi dan Kabupaten (B3) berada pada level tertinggi yang menjadi kendala utama dalam pengendalian pencemaran air Waduk Batujai. Sub elemen ini harus menjadi pokok kebijakan pemerintah daerah dalam upaya mengendalikan pencemaran Waduk Batujai. Sub elemen berikutnya adalah Ketersediaan Sumber Daya Manusia (B1), Ketersediaan Anggaran (B4), Kebijakan Pengendalian Waduk (B5), Regulasi yang Kurang Jelas (B6), Lemahnya Penegakan Hukum (B7), Penerapan green agriculture (B8), Koordinasi yang Lemah (B9), dan Organisasi Pengelola Belum Jelas (B10) menjadi program lanjutan yang dituangkan dalam rencana aksi pengendalian pencemaran Waduk Batujai.

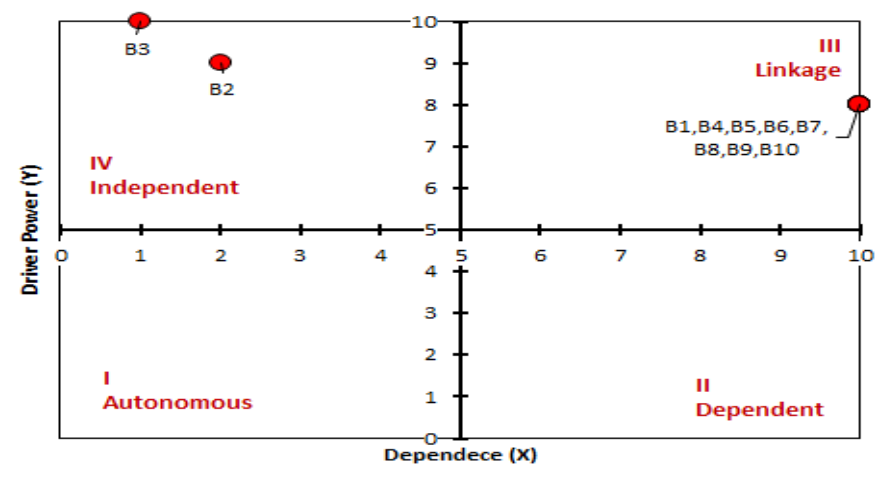

Gambar 4

Hubungan antar sub elemen kendala utama pengendalian pencemaran air Waduk Batujai 


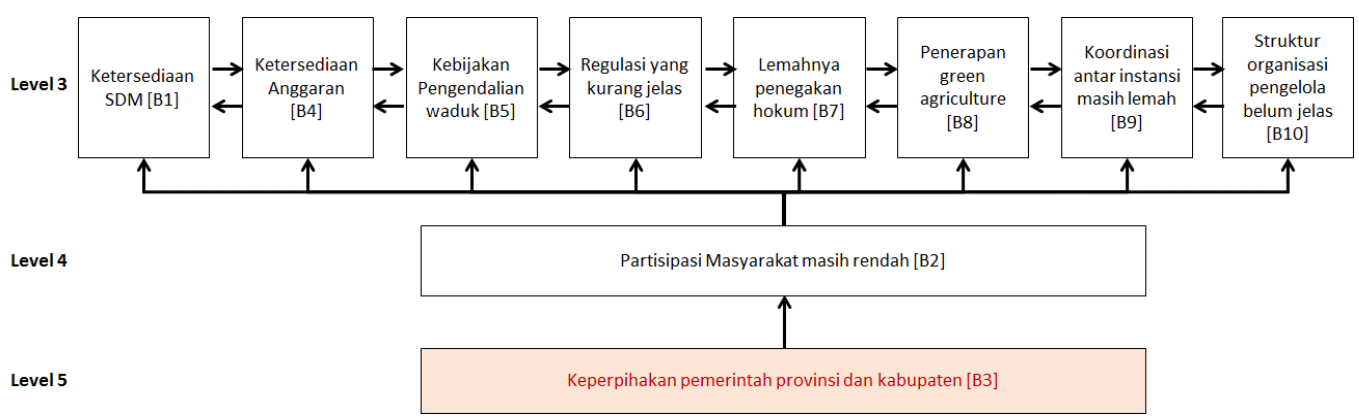

Gambar 5

Struktur hirarki sub elemen kendala utama pengendalian pencemaran air Waduk Batujai

\subsection{Tujuan dari Program Pengendalian Pencemaran Air Waduk Batujai}

Hasil analisis terhadap 7 sub elemen tujuan dari pengendalian pencemaran air Waduk Batujai diperoleh hasil bahwa Terciptanya tata kelola sampah swadaya (G1), Optimalisasi pemanfaatan Sumber Daya Manusia (G2) dan Peningkatan kinerja Balai Wilayah Sungai Provinsi NTB, DKP Kabupaten Lombok Tengah, dan DLH Lombok Kabupaten Tengah (G3). Sub elemen Terciptanya tata kelola sampah swadaya (G1), Optimalisasi pemanfaatan Sumber Daya Manusia (G2) dan Peningkatan kinerja Balai Wilayah Sungai Provinsi NTB, DKP Kabupaten Lombok Tengah, dan DLH Lombok Tengah (G3) mempunyai daya ungkit yang cukup kuat dalam mewujudkan pengendalian pencemaran air Waduk
Batujai. Sub elemen peningkatan kemampuan pengelolaan waduk (G5) dapat dipergunakan sebagai program dalam melaksanakan tujuan dari pengendalian pencemaran Waduk Batujai setelah program utama dilaksanakan, akan tetapi perlu kehati-hatian dalam penerapannya. Sub elemen Peningkatan keuntungan usaha perikanan (KJA) (G4), Kebijakan pemerintah daerah dalam penerapan green agriculture (G6) dan Peningkatan pendapatan asli daerah (G7) memiliki pengaruh yang kecil terhadap elemen tujuan. Sub elemen kunci dalam mencapai tujuan program dilakukan kolaborasi secara simultan akan mendukung perubahan peningkatan untuk capaian program, memecahkan beberapa permasalahan dan meminimalkan risiko program (Udayana et al., 2010).

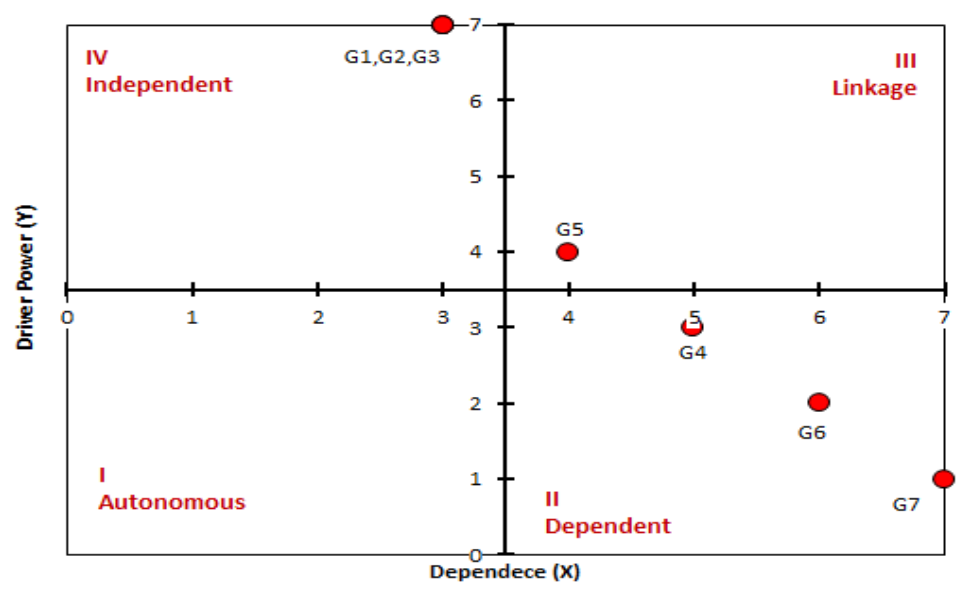

Gambar 6

Hubungan antar sub elemen tujuan dari pengendalian pencemaran air Waduk Batujai 


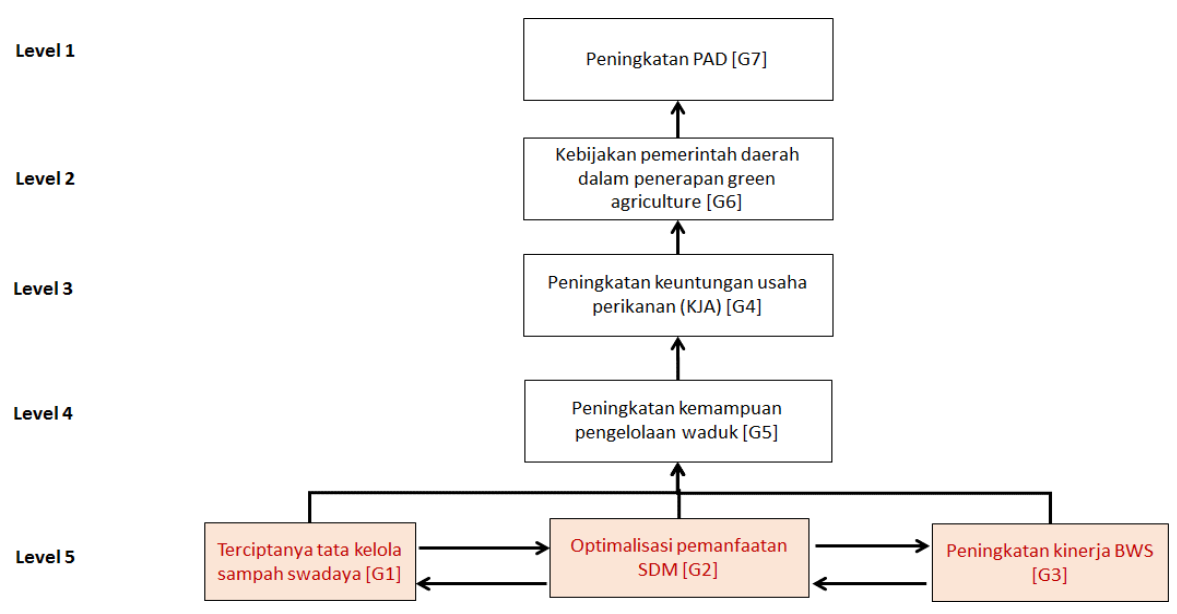

Gambar 7

Struktur hirarki sub elemen tujuan dari pengendalian pencemaran air Waduk Batujai

\subsection{Tolok Ukur Keberhasilan Pengendalian Pencemaran Air Waduk}

Hasil analisis terhadap 7 sub elemen tujuan dari pengendalian pencemaran air Waduk Batujai diperoleh hasil bahwa Penerapan Tata Ruang (T1) merupakan sub elemen utama sebagai tolok ukur keberhasilan pengendalian pencemaran air Waduk Batujai. Penerapan tata ruang (T1) mempunyai daya dorong yang sangat kuat sebagai tolok ukur keberhasilan pengendalian pencemaran air Waduk Batujai. Sub elemen Adanya peraturan pengendalian pencemaran air waduk (T2),
Kinerja instansi terkait lebih efisien (T3) dan Terbentuknya pengendalian pencemaran air waduk bersama masyarakat (T4) sebagai penyangga penerapan tata ruang. Sub elemen Adanya peraturan pengendalian pencemaran air waduk (T2), Kinerja instansi terkait lebih efisien (T3), Terbentuknya pengendalian pencemaran air waduk bersama masyarakat (T4) dan adanya koordinasi antar stakeholders (T5) dapat dipergunakan sebagai program pendamping program utama yaitu Penerapan tata ruang (T1).

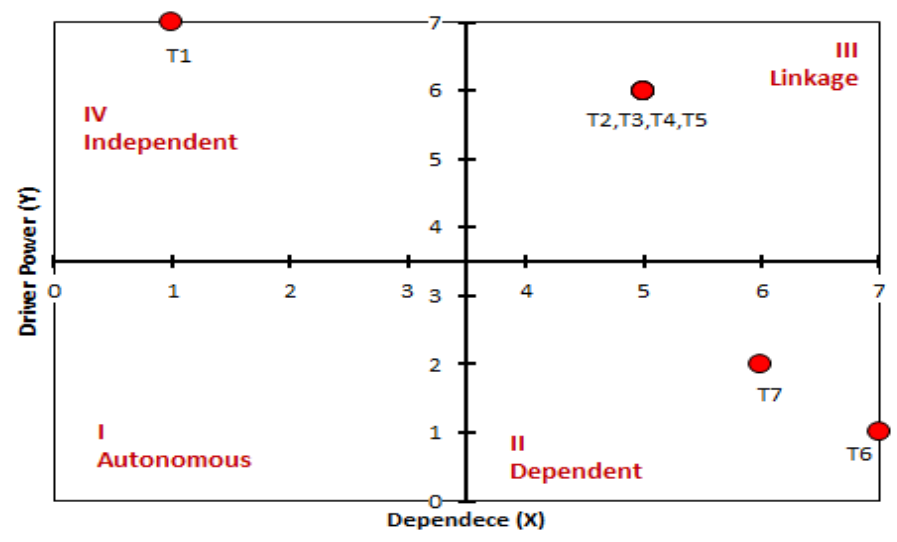

Gambar 8

Hubungan antar sub elemen tolok ukur keberhasilan pengendalian pencemaran air Waduk Batujai 
Sub elemen Pendapatan asli daerah meningkat (T6) dan Tidak terjadi konflik antar masyarakat yang memanfaatkan Waduk Batujai (T7) memiliki pengaruh yang kecil terhadap elemen tolok ukur keberhasilan pengendalian pencemaran air Waduk Batujai. Upaya pengendalian pencemaran air Waduk Batujai harus menempatkan penerapan tata ruang yang sesuai peruntukannya sebagai panglima dalam menilai tolok ukur keberhasilan program. Strategis yang dirancang untuk mengendalikan pencemaran lingkungan (Kholil et al., 2008).

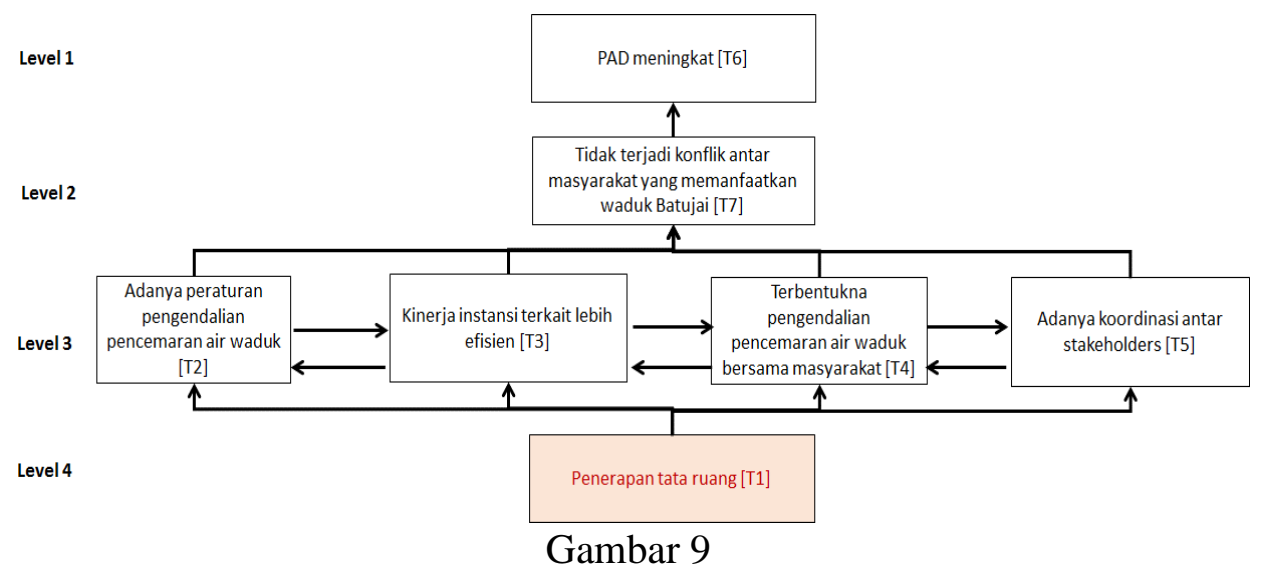

Struktur hirarki sub elemen tolok ukur keberhasilan pengendalian pencemaran air

Waduk Batujai

\subsection{Aktivitas yang Dibutuhkan dalam Pengendalian Pencemaran Air Waduk}

Hasil analisis terhadap 5 sub elemen aktivitas yang dibutuhkan dalam pengendalian pencemaran air Waduk Batujai diperoleh hasil bahwa Membina kelembagaan lingkungan adat (A1) dan Pembuatan regulasi pengendalian pencemaran air waduk (A3) merupakan aktivitas yang dibutuhkan dalam pengendalian pencemaran air Waduk Batujai. Sub elemen Membina kelembagaan lingkungan adat (A1) dan Pembuatan regulasi pengendalian pencemaran air waduk (A3) mempunyai pengaruh yang kuat untuk menunjang elemen aktivitas yang dibutuhkan dalam pengendalian pencemaran air Waduk Batujai.

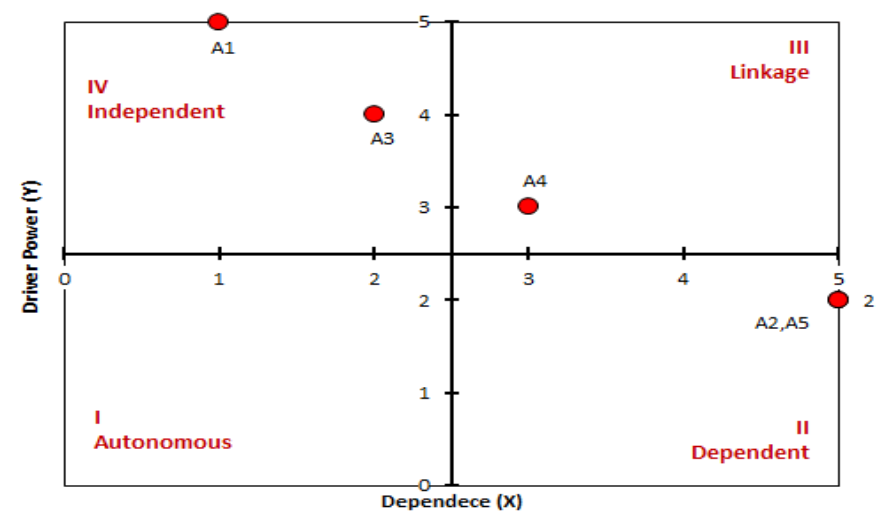

Gambar 10

Hubungan antar sub elemen tolok ukur keberhasilan pengendalian pencemaran air Waduk Batujai 
Sub elemen Penyediaaan sarana dan prasarana disekitar waduk (A4) dapat dipergunakan sebagai program pendamping program utama yaitu Membina kelembagaan lingkungan adat (A1) dan Pembuatan regulasi pengendalian pencemaran air waduk (A3) sebagai aktivitas yang dibutuhkan dalam pengendalian pencemaran air Waduk Batujai, akan tetapi perlu kehati-hatian dalam penerapannya. Sub elemen
Koordinasi dengan lembaga saling terkait (A2) dan Pengembangan akses informasi (A5) memiliki pengaruh yang kecil terhadap elemen aktivitas yang dibutuhkan dalam pengendalian pencemaran air Waduk Batujai. Memperkuat kelembagaan adat dengan memberikan ruang inovasi untuk kepentingan jangka panjang pengelolaan lingkungan Waduk Batujai (Santoso et al., 2017).

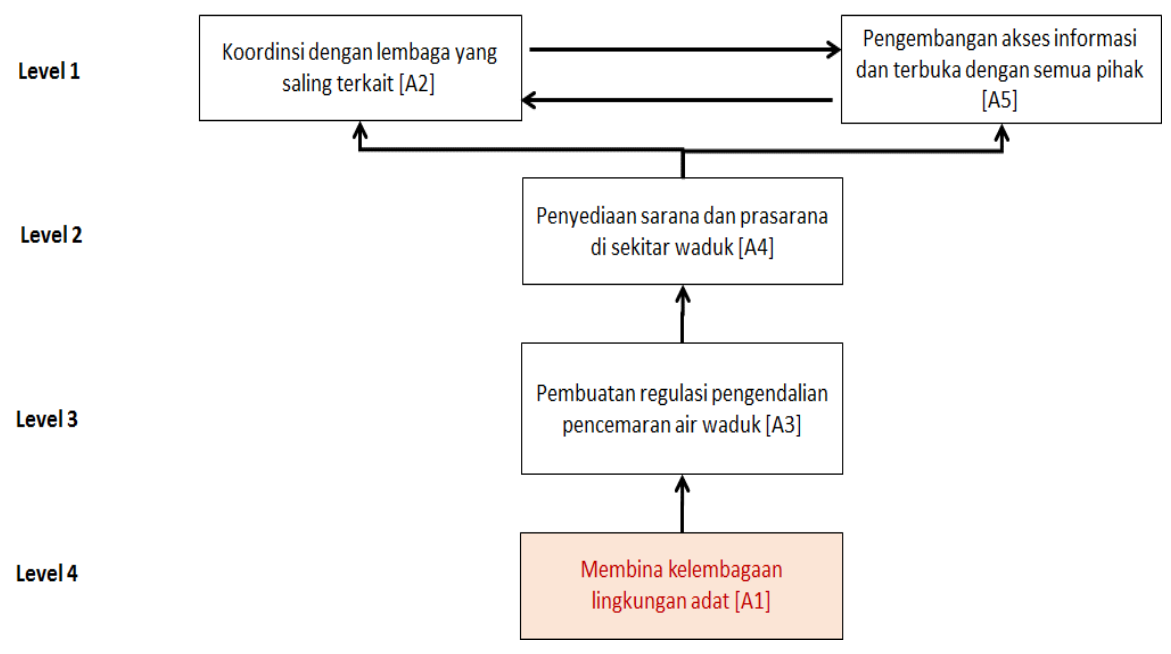

Gambar 11.

Struktur hirarki sub elemen tolok ukur keberhasilan pengendalian pencemaran air Waduk Batujai

3.6. Lembaga yang Terlibat Dalam Pengendalian Pencemaran Air Waduk

Hasil analisis terhadap 10 sub elemen lembaga yang terlibat dalam pengendalian pencemaran air Waduk Batujai menunjukkan bahwa Akademisi (L8), Lembaga Swadaya Masyarakat (L9), Tokoh Masyarakat (L10) dan Bappeda Kabupaten Lombok Tengah (A3). Hal ini menunjukkan bahwa Akademisi (L8), Lembaga Swadaya Masyarakat (L9), Tokoh Masyarakat (L10) dan Bappeda Kabupaten Lombok Tengah (A3) merupakan sub elemen yang menjadi ujung tombak yang berperan sangat penting sebagai lembaga yang terlibat dalam pengendalian pencemaran air Waduk Batujai dan mempunyai daya dorong yang kuat. 


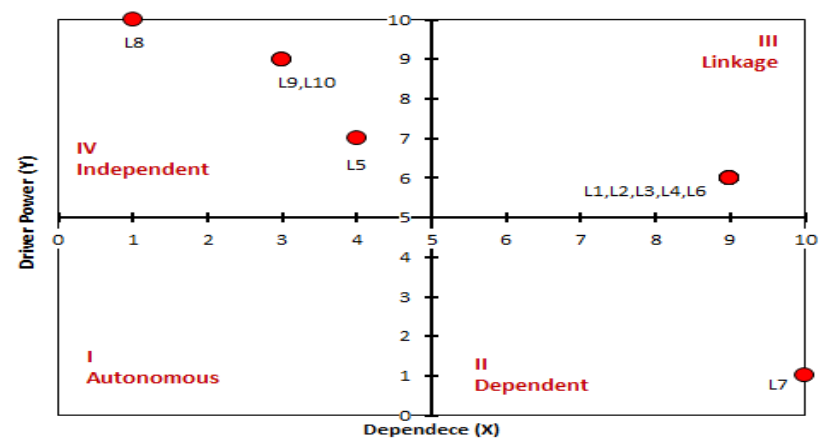

Gambar 12

Hubungan antar sub elemen lembaga yang terlibat dalam pengendalian pencemaran air Waduk Batujai

Sub elemen Dinas Lingkungan Hidup Kabupaten Lombok Tengah (L1), Dinas Perikanan dan Kelautan Kabupaten Lombok Tengah (L2), Dinas PUPR Kabupaten Lombok Tengah (L3), DPMPTSP Kabupaten Lombok Tengah (L4) dan Balai Wilayah Sungai Provinsi Nusa Tenggara Barat (L6) perlu kehatihatian dalam pelibatannya dan sebagai lembaga penunjang dalam pengendalian pencemaran air Waduk Batujai dalam menyusun model pengendalian pencemaran di Waduk Batujai. Sub elemen PDAM Kabupaten Lombok Tengah (L7) memiliki pengaruh yang kecil dalam pengendalian pencemaran air Waduk Batujai. Pengelolaan Waduk Batujai melibatkan berbagai sumber daya yang memliki kapasitas dan pemahaman yang sama (Djamhur et al., 2014).

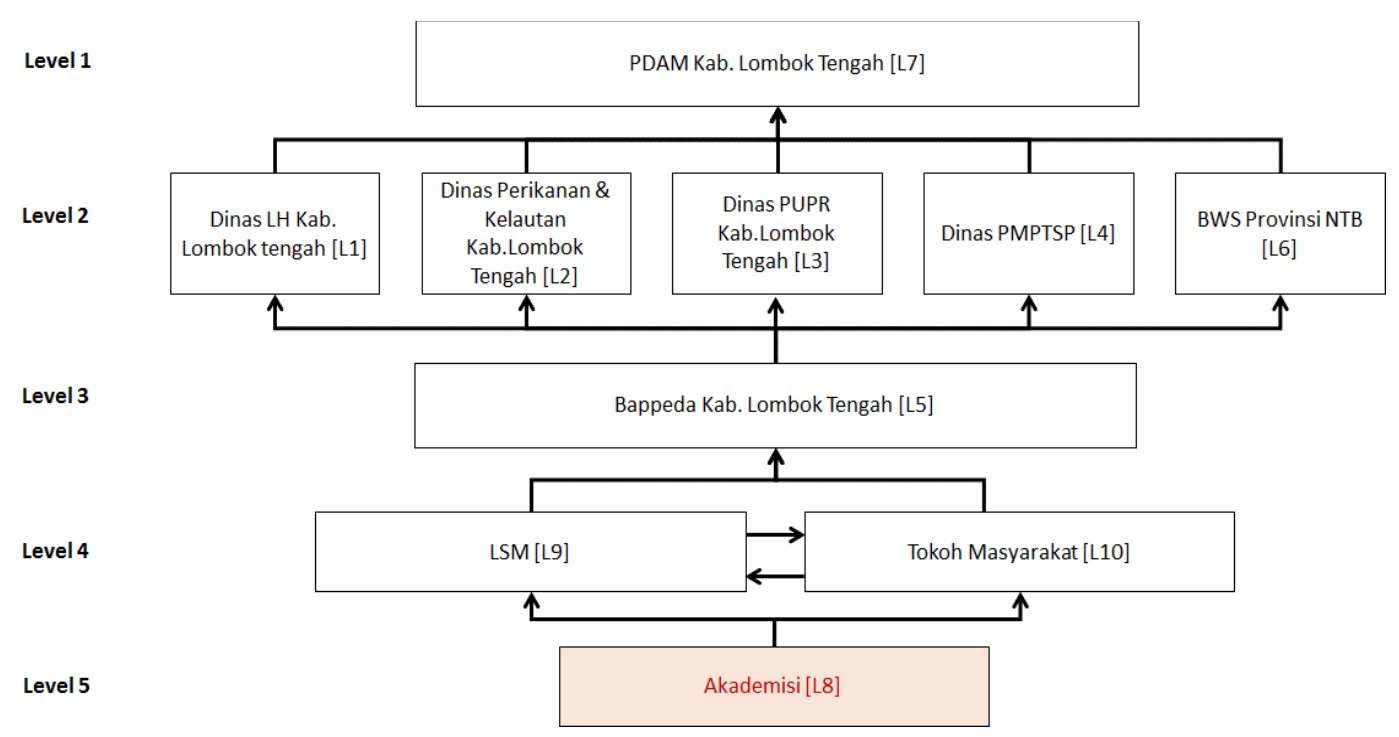

Gambar 13

Struktur hirarki sub elemen lembaga yang terlibat dalam pengendalian pencemaran air Waduk Batujai

3.7. Strategi Pencemaran Waduk Batujai

Berdasarkan 6 elemen diatas, yaitu (1) elemen kebutuhan terlaksana program pengendalian pencemaran air Waduk Batujai, (2) elemen kendala utama dalam pengendalian pencemaran air Waduk Batujai, (3) elemen Tujuan dari program 
pengendalian pencemaran air Waduk Batujai, (4) elemen Tolok ukur keberhasilan pengendalian pencemaran air Waduk Batujai, (5) elemen Aktivitas yang dibutuhkan dalam pengendalian pencemaran air Waduk Batujai, dan (6) Lembaga yang terlibat dalam pengendalian pencemaran air Waduk Batujai.

Strategi yang ditawarkan dalam mengendalikan pencemaran air di Waduk Batujai dapat dijelaskan sebagai berikut : tujuan dari penyusunan model pengendalian pencemaran air di Waduk Batujai adalah untuk terciptanya tata kelola sampah masyarakat, optimalisasi pemanfaatan sumber daya manusia, dan peningkatan kinerja Balai Wilayah Sungai Provinsi Nusa Tenggara Barat, ketiga tujuan ini dapat dijadikan prioritas utama dalam mewujudkan pengendalian pencemaran air Waduk Batujai. Peningkatan kemampuan pengelola waduk menjadi tujuan berikutnya setelah tujuan utama telah dilakukan, sedangkan peningkatan keuntungan usaha perikanan (karamba jaring apung), kebijakan pemerintah dalam penerapan green agriculture, dan peningkatan pendapatan asli daerah sebagai tujuan akhir dalam pengendalian pencemaran Waduk Batujai (Arnop et al., 2019).

Percepatan pencapaian tujuan pengendalian pencemaran air Waduk Batujai dilakukan dengan melibatkan stakeholder terkait seperti Dinas Lingkungan Hidup Kabupaten Lombok Tengah, Dinas Perikanan dan Kelautan Kabupaten Lombok Tengah, Dinas Pekerjaan Umum dan Penataan Ruang Kabupaten Lombok Tengah, Dinas Penanaman Modal Perijinan Terpadu Satu Pintu, Balai Wilayah Sungai Provinsi Nusa Tenggara Barat dan PDAM Lombok Tengah untuk bersama-sama terlibat dalam menyusun perencanan, penganggaran, menyusun rencana aksi dan pelaksanaan program di lapangan. Dalam mencapai tujuan pengendalian pencemaran air Waduk Batujai harus memperhatikan kebutuhan program yaitu ketersediaan anggaran dan Perbaikan sarana sanitasi dan IPAL sebagai kebutuhan program yang menjadi prioritas dalam upaya pengendalian pencemaran air Waduk Batujai. 


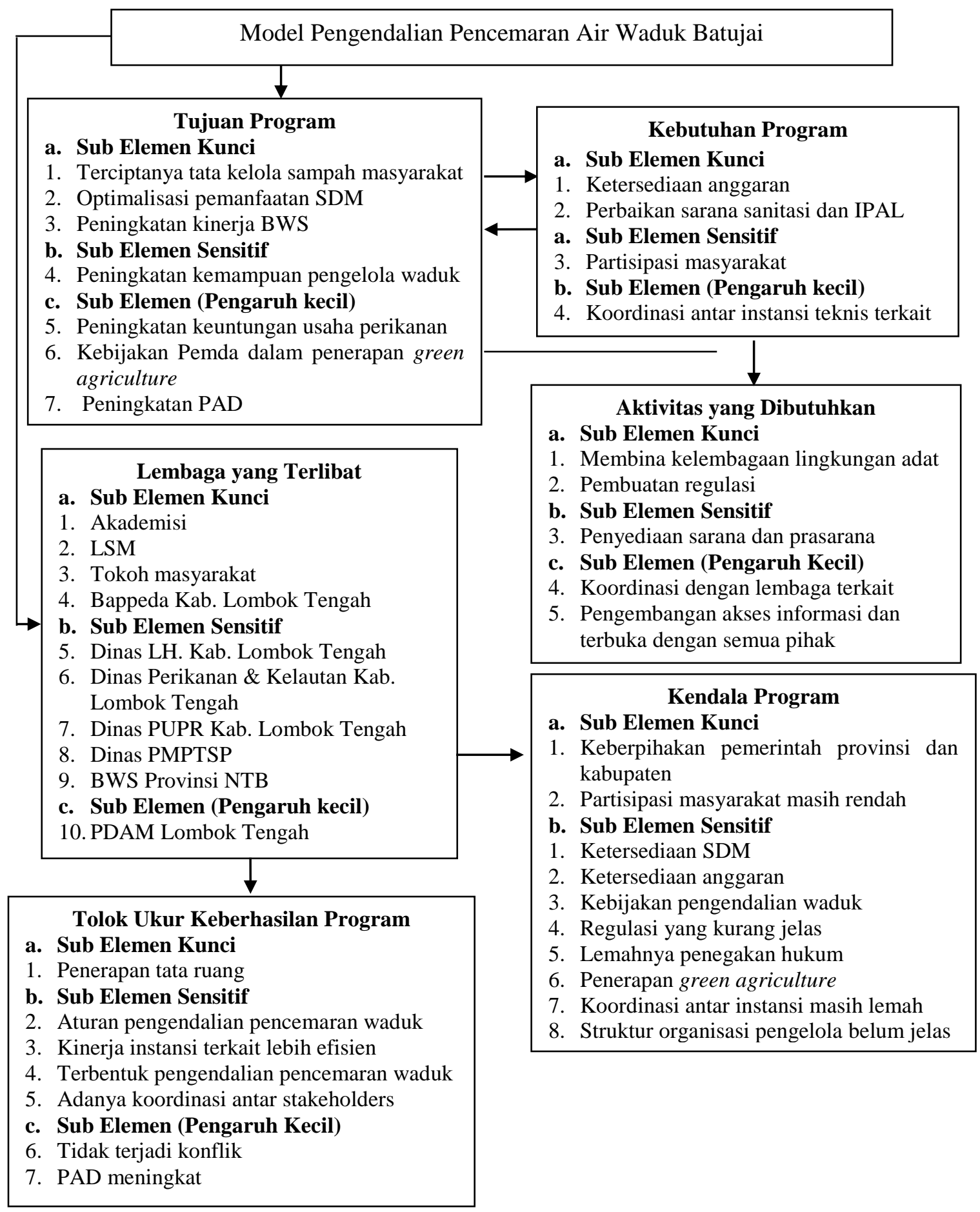

Gambar 14

Model Pengendalian Pencemaran Air Waduk Batujai

Kemudian disusul dengan stakeholders dalam mengendalikan meningkatkan partisipasi masyarakat pencemaran air Waduk Batujai sebagai untuk menggugah kesadaran masyarakat dan diperkuat dengan membuat regulasi yang mengatur tentang tata cara partisipasi masyarakat delam pengelolaan lingkungan hidup. Peran masing-masing

berikut:

a. Instansi terkait

1. Memperkuat dukungan perencanaan dan dukungan anggaran; 
2. Menegaskan regulasi, menegakkan hukum, memberikan reward dan funishment secara tegas dengan melibatkan unsur penegak hukum; dan

3. Membuat atau merestrukturisasi kelembagaan Waduk Batujai dengan melibatkan stakeholders terkait yang didukung dengan regulasi dan pendanaan yang jelas.

b. Akademisi
1. Menyusun $\begin{array}{lr}\text { kajian teknis } & \\ \text { pencemaran } & \text { air }\end{array}$ pengendalian Waduk Batujai;

2. Memberikan Pemerintah masukan kepada Tengah; dan

3. Merumuskan pengelolaan pencemaran Waduk Batujai.

c. Lembaga Swadaya Masyarakat

1. Melaksanakan pembinaan dan pemberdayaan kepada masyarakat dan pendampingan masyarakat;

2. Memberikan edukasi tentang lingkungan kepada masyarakat; dan

3. Mendorong percepatan pengendalian pencemaran air Waduk Batujai dan menjalin kerjasama dengan pemerintah daerah.

d. Tokoh Masyarakat

1. Memberikan dukungan kepada pemerintah daerah dengan melakukan pendekatan kepada masyarakat;

2. Melakukan sosialisasi bersama pemerintah dalam mengendalikan pencemaran air Waduk Batujai;

Untuk memperkuat upaya pengendalian pencemaran air Waduk Batujai perlu dilakukan pembinaan kelembagaan lingkungan adat untuk memberikan pelatihan kepada masyarakat adat dan ikut berpartisipasi dengan menggunakan kearifan lokal dan Pemerintah Daerah Kabupaten Lombok
Tengah membuat regulasi untuk memberikan kepastian hukum dalam mendorong percepatan pengendalian pencemaran air Waduk Batujai (Yohanes et al., 2019). Peran kelembagaan adat dan pembuatan regulasi merupakan pendorong yang kuat untuk mendukung pelaksanaan program, kemudian disusul dengan penyediaan sarana dan prasarana pendukung, koordinasi dengan lembaga terkait dan pengembangan akses informasi sebagai program pendukung penguatan aktivitas pengendalian pencemaran air Waduk Batujai (Dawud et al., 2016). Keberpihakan pemerintah provinsi dan kabupaten serta peningkatan partisipasi masyarakat yang masih rendah sebagai kendala utama keberhasilan program perlu ditingkatkan dengan melakukan dialog dan pelibatan semua stakeholder dalam perencanaan (Agustiningsih, 2012). Ketersediaan sumberdaya manusia, ketersediaan anggaran, kebijakan pengendalian waduk, regulasi yang kurang jelas, lemahnya penegakan hukum, penerapan green agriculture, koordinasi antar instansi masih lemah, dan struktur organisasi pengelola belum menjadi program berikutnya yang harus mendapat penanganan secara terstruktur dan diimplementasikan melalui rencana aksi.

\section{SIMPULAN DAN SARAN}

\subsection{Simpulan}

Model pengendalian pencemaran air Waduk Batujai dilakukan melalui terciptanya tata kelola sampah masyarakat dan optimalisasi pemanfaatan sumber daya manusia menjadi penggerak utama dalam pencapaian tujuan. Ketersediaan anggaran dan perbaikan sarana sanitasi dan IPAL merupakan penggerak utama program. Aktivitas untuk menunjang keberhasilan program dilakukan dengan membina kelembagaan lingkungan adat dan pembuatan regulasi yang berpihak pada keberlajutan lingkungan hidup. 
Kendala utama program adalah Keberpihakan pemerintah provinsi dan kabupaten dan partisipasi masyarakat masih rendah dan tolok ukur keberhasilan program dengan menerapkan tata ruang sesuai dengan peruntukannya. Pengendalian pencemaran Waduk batujai dilakukan dengan melibatkan seluruh stakeholders terkait dengan menempatkan akdemisi, LSM dan Bappeda Lombok Tengah sebagai pendorong utama pelaksanaan program dan menggunakan pendekatan kearifan lokal.

\subsection{Saran}

Mendorong percepatan pengendalian pencemaran air Waduk Batujai dengan pendekatan partisipatif dan menggunakan pendekatan kearifan lokal, melibatkan seluruh stakeholders kunci.

\section{DAFTAR PUSTAKA}

Agustiningsih, D., \& Sasongko, S. B. (2012). Analisis Kualitas Air Dan Strategi Pengendalian Pencemaran Air Sungai Blukar Kabupaten Kendal. Jurnal Presipitasi, 9(2), 64-71-71

Armadi, M., Suarna, W., Sudarma, M., Mahendra, M, S., Sudipa, N. 2020. Model Pengelolaan Sampah Berbasis Masyarakat di Kota Denpasar. 14 (2). 131-142

Arnop, O., Budiyanto, B., \& Saefuddin, R. (2019). Kajian Evaluasi Mutu Sungai Nelas Dengan Metode Storet Dan Indeks Pencemaran. Naturalis: Jurnal Penelitian Pengelolaan Sumber Daya Alam Dan Lingkungan, 8(1), 15-24.

Attri, R., Dev, N., and Sharma, V. 2013. Interpretative Structural Modelling (ISM) Approach: An Overview. Research Journal of Management Sciences ISSN 2319-1171.

Dawud, M., Namara, I., Chayati, N., \& Taqwa, F. M. L. (2016). Analisis
Sistem Pengendalian Pencemaran Air Sungai Cisadane Kota Tangerang Berbasis Masyarakat. Jurnal Umj, 1-8.

Djamhur, M., Boer, M., Bengen, D. G., \& Fahrudin, A. (2016). Pemodelan Interpretasi Struktural Pengembangan Kawasan Pesisir Dan Pulau-Pulau Kecil Di Teluk Weda. Jurnal Sosial Ekonomi Kelautan Dan Perikanan, 9(2), 127.

Laapo, A., Fahrudin., A., Bengen. D. G., Damar, A. 2009. Pengaruh Aktivitas Wisata Bahari terhadap Kualitas Perairan Laut di Kawasan Wisata Gugus Pulau Togean; Ilmu Kelautan: 14 (4): 215-221

Octhreeani, G. A., Supriharyono., Soedarsono, P. 2014. Pengaruh Perbedaan Jenis Pupuk Terhadap Pertumbuhan Nannochloropsis SP. Dilihat Dari Kepadatan Sel dan Klorofil A Pada Skala Semi Massal; Diponegoro Journal of Maquares management of Aquatic Resources: 3 (2): 102-108.

Kanungo S dan V.V. Batnagar, 2002. Beyond Generic Models for Information System Quality : The Use of Interpretative Structural Modelling (ISM); Journal of System Research and Behavior Science. Vol. 19:pp 531:549.

Kholil , Eriyatno, Sutjahyo, S, H., Soekarto, S, H. (2008). Pengembangan Model Kelembagaan Pengelola Sampah Kota dengan Metode ISM (Interpretative Structural Modeling) Studi Kasus di Jakarta Selatan. Sodality: Jurnal Sosiologi Pedesaan, 2(1), 31-48.

Maharani, A. Ciptomulyono U, Santosa B. 2008. Pengembangan Model Optimasi Manajemen Pengelolaan Kualitas Air Kali Surabaya dengan 
Interval Fuzzy Linier Programming (IFLP). Prosiding Seminar Nasional Manajemen Teknologi VIII Institut Teknologi Sepuluh Nopember Surabaya, Surabaya 2 Agustus 2008.

Nandalal, K.D.W., Sumasinghe, S.B.A.D. 2006. A Sistem Dynamics Simulation Model for the Assessment of Water Resources in Sri Lanka. 32nd WEDC International Conference, Colombo Sri Lanka

Nikoo, M.R. Kerachian, R. Karimi, A. and Azadnia, A.A. 2013. Optimal water and waste-load allocations in rivers using a fuzzy transformation technique: a case study. Environ Monit Assess (2013) 185:24832502 DOI 10.1007/s10661-0122726-6. Springer Science+Business Media B.V. 2012.

Panggabean, T. K., Sasanti. A. D., Yulisman. 2016. Kualitas Air, Kelangsungan Hidup, Pertumbuhan, dan Efisiensi Pakan Ikan Nila yang diberi Pupuk Hayati Cair pada Air Media Pemeliharaan; Jurnal Akuakultur Rawa Indonesia: 4 (1) : 67-79

Pramono, A. J., \& Hendharto, H. (2017). Model Transformasi Badan Pemeriksa Keuangan Republik Indonesia. Jurnal Tata Kelola Dan Akuntabilitas Keuangan Negara, 91-111.

Rosadi, Purwanto, M. Y. J., Sutjahyo, S. H., \& Pramudya, B. (2016). Sistem pengembangan kelembagaan Agroindustri padi pada sekala kecil dan menengah. Jurnal Sosial Ekonomi Pekerjaan Umum, 8(2), 123-131.

Sriyanto. 2007. Kondisi Lingkungan Hidup Di Jawa Tengah dan Prospek Pembangunan ke Depan. Jurnal Geografi, 4(2), 107-113.
Sudipa $_{\mathrm{a}}$, N., Mahendra, M. S., Adnyana, W. S., \& Pujaastawa, I. B. 2020a. Daya Dukung Air di Kawasan Pariwisata Nusa Penida, Bali. Jurnal Suberdaya Alam dan Lingkungan. 7 (3). 117-123

Sudipa $a_{b}$, N., Mahendra, M. S., Adnyana, W. S., \& Pujaastawa, I. B. 2020b. Status daya Dukung Air di kawasan Pariwisata Nusa Penida, Bali. Jurnal Ecotrophic. 14 (2). 181-189

Sudipa $_{c}$, N., Mahendra, M. S., Adnyana, W. S., \& Pujaastawa, I. B. $2020_{\text {c. }}$. Tourism Impact on the Environment in Nusa Penida Tourism Area. Journal Inveronmental Management and Tourism. XI (41), 113-124

Sudipa $_{d}$, N., Mahendra, M. S., Adnyana, W. S., \& Pujaastawa, I. B. 2020d. Alih Fungsi Lahan di Kawasan Pariwisata Nusa Penida. 6 (2). 182-191

Sudipa $a_{e}$ N., Mahendra, M. S., Adnyana, W. S., \& Pujaastawa, I. B. 2020e. Model Pengelolaan Lingkungan di Kawasan Pariwisata Nusa Penida, Bali. Jurnal Ecotrophic. 14 (1). 113

Samadikun, B., P., Sudibyakto, Setiawan, B., Rijanta. 2012. Model Perencanaan dan Pengelolaan Lingkungan (Kasus; Bentang Lahan Kawasan Tembalang Semarang); Vol. 9. No. 1: pp 17-20. Jurnal Presipitasi.

Basuki Kuwat Santoso, P., Sabiham, S., \& Wayan Rusastra, I. (2017). Analisis Pola Konversi Lahan Sawah dan Struktur Hubungan Penyebab dan Pencegahannya (Studi Kasus Kabupaten Subang, Provinsi Jawa Barat). Jurnal Pengelolaan Sumberdaya Alam Dan Lingkungan, 7(2), 184-194. 
Saxena, J. P. 1992. Hierarchy and Classification of Program Plan Element Using Interpretative Structural Modelling.12 (6):P 651:670. Systems Practice.

Udayana, I. G. B., Eriyatno, Hambali, E., \& Fauzi, A. M. (2010). Pengembangan Model Kelembagaan sebagi Solusi Kelapa Sawit. Jurnal Agritek, 11(2), 10 20.

Utami, N.M.N. 2004. Dampak Industri Pariwisata Terhadap Kualitas Air Tanah di Kuta, Bali, Disertasi. Program Studi Ilmu Lingkungan
Pascasarjana, Universitas Indonesia.

Yohannes, B. Y., Utomo, S. W., \& Agustina, H. (2019). Kajian Kualitas Air Sungai dan Upaya Pengendalian Pencemaran Air. IJEEM - Indonesian Journal of Environmental Education and Management, 4(2), 136-155

Zhang, H. Zhang, X. and B. Zhang. 2009. Sistem Dinamic Approach to Urban Water Demand Forecasting. Transaction of Tianjin University, 15 (1):70-74. 